\title{
Adaptability and yield stability of soybean genotypes by mean Eberhart and Russell methods, artificial neural networks and centroid
}

\author{
Mario do Carmo Oda ${ }^{1}$, Tuneo Sediyama ${ }^{2}$, Cosme Damião $\operatorname{Cruz}^{3} \mathbb{D}^{\mathbb{D}}$, \\ Moysés Nascimento ${ }^{4}$ and Éder Matsuo ${ }^{5, *}$
}

\begin{abstract}
${ }^{1}$ Researcher, TMG: Tropical Melhoramento \& Genética, Highway PR 445, Km 87 S/N, Lote247, Gleba Jacutinga, Cambé, PR, Brazil, CEP 86183-600. 2Department of Agronomy, Federal University of Viçosa, Viçosa Campus, Viçosa, MG, Brazil, CEP 36570-900. ${ }^{3}$ Department of Biology, Federal University of Viçosa, Viçosa Campus, Viçosa, MG, Brazil, CEP 36570-900. ${ }^{4}$ Department of Statistics, Federal University of Viçosa, Viçosa Campus, Viçosa, MG, Brazil, CEP 36570-900. ${ }^{5}$ Technological and Exact Sciences Institute, Federal University of Viçosa, Rio Paranaíba Campus, Biostatistics Laboratory, Highway MG 230, Km 7, PO Box 22, Rio Paranaiba, MG, Brazil, CEP 38810-000. *Corresponding author, E-mail: edermatsuo@ufv.br
\end{abstract}

\section{ABSTRACT}

Gopen access

Citation: Oda, C. M., Sediyama, T., Cruz, D. C., Nascimento, M., \& Matsuo, E. (2022). Adaptability and yield stability of soybean genotypes by mean eberhart and Russell methods, artificial neural networks centroid. Agronomy Science and Biotechnology, 8, 1-13 https://doi.org/10.33158/ASB.r142.v8.2 $\underline{022}$

Received: July 29, 2021. Accepted: August 17, 2021.

Published: October 01, 2021.

English by: André Luis Miyagaki.

Copyright:@ 2022 Agronomy Science and Biotechnology. This is an open access article distributed under the terms of the Creative Commons Attribution License, which permits unrestricted use, distribution, and reproduction in any medium, since the original author and source are credited.
The soybean crop is prominent in national and international scenarios. A large part of the world production of soybean is cultivated in Brazil and this has been possible due to the performance of different technological areas, among them genetics and plant breeding. Soybean breeding has acted in the development and launch of new cultivars and for this it is required the studies of interaction genotypes $x$ environments and those of adaptability and stability. Thus, the objective was to evaluate the adaptability and phenotypic stability of the grain yield of late-cycle soybean genotypes. Five experiments were conducted in the state of Minas Gerais, each of which was considered as an environment. In each, 17 soybean genotypes were evaluated in a randomized block design with three repetitions, for grain yield, in $\mathrm{kg} \mathrm{ha}^{-1}$. The data were analyzed by means of individual (each environment) and joint analysis of variance. Subsequently, analyses of adaptability and phenotypic stability were performed using the methods of Eberhart and Russell (1966), Artificial Neural Networks (Nascimento et al., 2013) and Centroid (Rocha, Muro-Abad, Araujo, \& Cruz, 2005). The results indicated the classification of the analyzed genotypes for unfavorable, general or favorable adaptability, with high or low stability. DM-339 is indicated for favorable environments and UFV-18 (Patos de Minas), UFV91-651226, UFV99-8552093, UFV01-871375B, UFV01-66322813 and UFV99-8552099 are indicated as general adaptability, considering the three methods of adaptability and stability analysis.

Keywords: Glycine max, genetic improvement, interaction, artificial intelligence, agriculture, statistics. 


\section{INTRODUCTION}

The soybean crop Glycine max (L.) Merrill has stood out in the national and international agricultural scenario. Faced with this evolution in soybean production and grain yield is the launch of improved cultivars adapted to various growing regions (Santos, Silva, Sediyama, \& Soares, 2016).

The evaluation of grain yield in soybean improvement is one of the most costly and time-consuming phases, and the new strain should be compared with at least two standard cultivars of the cultivation region (within a certain maturity group) (Sediyama, Matsuo, Oliveira, \& Glasenapp, 2015). In experimental terms, the number of repetitions and the number of test locations are very important factors in the selection of superior strains. In the first year, it is recommended that two locations be used for evaluation. In the second year of the trial, the number of locations will depend on the resources available and the extent of the area to be commercially cultivated. In the third and fourth years of the trial, it is recommended that the test locations be as broad as possible, to obtain information about the extent of adaptation of the strain to be released as a new cultivar (Sediyama et al., 2015).

When a series of environments is considered, it is possible to detect, in addition to the genetic and environmental effects, an additional effect provided by their interaction (Cruz et al., 2004). The evaluation of the interaction genotypes $x$ environments becomes of great importance in breeding, because if it exists, there is the possibility that the best genotype in one environment is not in another, and this fact, according to the authors, hinders the recommendation of cultivars with wide adaptability (Cruz, Rodrigues, Rosado, \& Bhering, 2017). The identification of cultivars with predictable behavior and that are responsive to environmental variations, under specific or broad conditions, can be performed through the analysis of adaptability and stability (Cruz, Regazzi, \& Carneiro, 2004). Careful studies of adaptability and yield stability in soybean should be carried out to ensure greater safety to the recommendations of cultivars (Sediyama, Oliveira, \& Cruz, 1990). Several methods have been proposed for the evaluation of adaptability and phenotypic stability, where the difference between them is based on the very biometric concepts and procedures to quantify the GXA interaction (Rodrigues et al., 2020). The choice of the best method depends on the experimental data, mainly related to the number of environments available, the required precision and the type of information desired (Cruz et al., 2004).

Although there are numerous methodologies for adaptability and stability analysis, the proposal by Eberhart and Russell (1966) has still been one of the most used directly in soybean improvement or as a reference for others that involve different approaches (Cruz et al., 2017), as in the proposal by Nascimento et al. (2013). According to Rezende, Cruz, Borém and Rosado (2021) the method of Eberhart and Russell (1966) has been predominant in the study of adaptability and stability in soybean and corn crops for the last 50 years.

Most methods used to evaluate the adaptability and stability of genotypes require basic assumptions, such as normal distribution of data, independence of variances, and the existence of a statistical model associated with an experimental design (Di Mauro, Curcioli, Nóbrega, Banzato, \& Sediyama, 2000). The classification of genotypes using artificial neural networks (ANN), proposed by Nascimento et al. (2013), specifically for adaptability and stability analysis, does not require prior knowledge regarding the behavior to be modeled and no assumptions regarding the variables under study (Nascimento, Nascimento, \& Barroso, 2018). In soybean, 
the ANN method proposed by Nascimento et al. (2013) was used to evaluate the stability and adaptability of grain yield of soybean elite lines (Oda, Sediyama, Matsuo, Nascimento, \& Cruz, 2019) and to identify soybean cultivars with stability and predictability of behavior regarding hypocotyl length (Alves et al., 2019).

Thus, the objective was to evaluate the adaptability and phenotypic stability of the grain yield of a group of late-cycle soybean lines.

\section{MATERIAL AND METHODS}

Experiments were conducted in order to evaluate the grain yield, in $\mathrm{kg} \mathrm{ha}^{-1}$, of 17 soybean genotypes, namely: 13 late-cycle soybean lines belonging to the Soybean Genetic Improvement Program of the Department of Plant Science (Agronomy) at the Federal University of Viçosa, focused on the state of Minas Gerais, and four cultivars (UFV18 - Patos de Minas, BRS-Celeste, DM-339 and MSOY 8914) widely used in the state.

The experiments were conducted in the agricultural years of 2002/03 and 2003/04, totalizing five environments in the state of Minas Gerais:

Environment 1 = Capinópolis, fertile soil, $620 \mathrm{~m}$ of altitude, with coordinates $18^{\circ} 41^{\prime} 05$ "S and 49 $34^{\prime} 51$ "W, in the 2002/2003 agricultural year;

Environment 2 = Capinópolis, poor soil, $620 \mathrm{~m}$ of altitude, with coordinates $18^{\circ} 41^{\prime} 05$ "S and $49^{\circ} 34^{\prime} 51$ "W, in the 2002/2003 agricultural year;

Environment 3 = Florestal, poor soil, $796 \mathrm{~m}$ of altitude, with coordinates $19^{\circ} 52^{\prime} 26^{\prime \prime S}$ and $42^{\circ} 26^{\prime} 17$ "W, in the 2002/2003 agricultural year;

Environment 4 = Capinópolis, fertile soil, $620 \mathrm{~m}$ of altitude, with coordinates $18^{\circ} 41^{\prime} 05$ "S and $49^{\circ} 34^{\prime} 51$ "W, in the 2003/2004 agricultural year; and

Environment 5 = Capinópolis, poor soil, $620 \mathrm{~m}$ of altitude, with coordinates $18^{\circ} 41^{\prime} 05$ "S and $49^{\circ} 34^{\prime} 51$ "W, in the 2003/2004 agricultural year.

In each environment, the experiment was set up in a randomized block design with three repetitions (blocks). The plots were formed by four rows of plants, $5.0 \mathrm{~m}$ long, spaced $0.50 \mathrm{~m}$ apart. The useful area of the plot was $4.0 \mathrm{~m}^{2}$, with the two central rows being harvested, disregarding $0.50 \mathrm{~m}$ of border at the extremities, later threshed and, when necessary, the grains were dried up to $14 \%$ humidity, to obtain the production per plot. With this result it was obtained the yield in $\mathrm{kg} \mathrm{ha}^{-1}$.

The results were submitted to the individual analysis of variance for each environment considering previous tests to evaluate the normality of errors and homogeneity of variances. They were followed by the joint analysis of variance to evaluate the homogeneity of the residual variances of the experiments and we used the ratio between the largest and smallest residual mean square of the individual trials. it was considered homogeneous variances if this ratio is less than 7.0 according to Pimentel-Gomes (1990). The analysis of variance was performed using the randomized block model, consisting of fixed effects for genotypes and random effects for environments and interaction of genotypes $x$ environments. The model for this analysis is given by:

$$
Y_{i j k}=m+G_{i}+B / A_{j k}+A_{k}+G A_{i k}+E_{i j k}
$$

where:

$Y_{i j k}$ is the observed value of grain yield in genotype $i$ in block $j$ and within environment $k$;

$m$ is the overall mean;

$G_{i}$ is the fixed effect of genotype $i$; 
$B / A_{j k}$ is the random effect of block $j$ within environment $k$;

$A_{k}$ is the random effect of environment $k$;

$G A_{i k}$ is the random effect of the interaction of genotype $i$ with environment $k$; and

$E_{i j k}$ is the experimental error.

Phenotypic adaptability and stability analyses were performed by the methods of Eberhart and Russell (1966), Artificial Neural Networks (Nascimento et al., 2013) and Centroid (Rocha et al., 2005).

The method proposed by Eberhart and Russell (1966) is based on the simple linear regression analysis, which measures the response of each genotype to environmental variations. The estimator of the adaptability parameter is given by $\hat{\beta}_{1 i}$ being the hypothesis $H_{0}: \beta_{1 i}=1$ versus $H_{a}: \beta_{1 i} \neq 1$ evaluated by the $t$-test at $5 \%$ significance level. The estimator of the stability parameter is given by $\hat{\sigma}_{d i}^{2}$ with the hypothesis $H_{0}: \sigma_{d i}^{2}=0$ versus $H_{a}: \sigma_{d i}^{2}>0$ and evaluated by the $F$-test at $5 \%$ significance (Eberhart \& Russell, 1966). These authors proposed that those genotypes, of good average, with $\beta_{1 i}>1$ are classified with specific adaptability to favorable environments; with $\beta_{1 i}=1$ are classified with general adaptability; and with $\beta_{1 i}<1$ are classified with specific adaptability to unfavorable environments. As for stability, genotypes with $\sigma_{d i}^{2}=0$ are classified as having high predictability and those with $\sigma_{d i}^{2}>0$ are classified as having low predictability; the coefficient of determination $\left(R_{\%}^{2}\right)$ for each genotype (Eberhart \& Russell, 1966) was also estimated as an auxiliary measure of stability.

Regarding the artificial neural network (ANN), the data set used for training purposes is established by simulation from the parameters of the model of Eberhart and Russell (1966), and the criteria for the classification of cultivars as to adaptability and stability by the ANN were established as described by Nascimento et al. (2013). In the present work, the neural network, of the perceptron type, with back-propagation single hidden layer training algorithm was used. Specifically, the ANN has 1 input layer, 1 intermediate layer, and 1 output layer. The first layer has 5 inputs, which refer to the average yield values evaluated in 5 environments. In the intermediate layer, the number of neurons varied from 1 to 10 neurons.

The output layer was composed of 1 neuron and the output was given by the classification of the genotype in one of six classes defined by Eberhart and Russell (1966):

Class 1: General adaptability and low predictability;

Class 2: Specific adaptability to favorable environments and low predictability;

Class 3: Specific adaptability to unfavorable environments and low predictability;

Class 4: General adaptability and high predictability;

Class 5: Specific adaptability to favorable environments and high predictability; and

Class 6: Specific adaptability to unfavorable environments and high predictability.

The necessary arguments for the network function, such as number of neurons in the hidden layer, initial values for the weights, decay rate and maximum iterations were chosen considering the network that provided an error value of at most $2 \%$ for the test set, as performed by Nascimento et al. (2013) and Barroso, Nascimento, Nascimento, Silva and Ferreira (2013). The best network architecture was established considering a classification error of less than $2 \%$. For ANN analysis, of the 17 soybean genotypes under study, the nnet function of the nnet package (Venables \& Ripley, 2002) implemented in R (R Core Team, 2021) was used for 
adaptability evaluation by means of the artificial neural network.

The Centroid method (Rocha et al., 2005) is a non-parametric method that aims to facilitate the recommendation of genotypes, because it allows the direction of the genotypes in relation to environmental variation, dispensing with the analysis of several parameters, as occurs in regression-based methods. Then, the Centroid method is based on the comparison of Cartesian distance values between the genotypes and four ideal references (ideotypes), created based on experimental data to represent the genotypes of maximum general adaptability, maximum specific adaptability to favorable or unfavorable environments and the genotypes of minimum adaptability (Rocha et al., 2005).

The genotypes can be classified in one of the ideotypes:

Ideotype I: presents maximum general adaptability, having maximum values observed in all environments;

Ideotype II: has maximum specific adaptability to favorable environment, presenting maximum response in favorable environment and minimum in unfavorable environment;

Ideotype III: has maximum specific adaptability to unfavorable environment, presenting maximum response in unfavorable environment and minimum in favorable environment; or

Ideotype IV: has minimum adaptability, presenting minimum values observed in all environments (Rocha et al., 2005).

To use this method, the environments are classified into favorable and unfavorable, using the environmental index proposed by Finlay and Wilkinson (1963). Consequently, according to the authors, in one of the classes: Class I: general adaptability; Class II: specific adaptability to favorable environments; Class III: specific adaptability to unfavorable environments; Class IV: poorly adapted (Rocha et al., 2005). The concept of adaptability and stability used in the Centroid method considers that the genotype of maximum specific adaptability is not the one that presents good performance in the groups of favorable or unfavorable environments, but the genotype that presents maximum values for a certain group of environments (favorable and unfavorable) and minimum for the other set (Rocha et al., 2005).

The statistical analyses, except for ANN, were performed in the Genes Program (Cruz, 2013).

\section{RESULTS AND DISCUSSION}

For the individual environments, the Bartllet test indicated that the variances are homogeneous and by means of the Lilliefors test it was possible to verify that it is reasonable to study the residuals, of the anova, by means of the normal distribution, with this, it enabled the use of analysis of variance without requiring data transformation. The effect of genotype in all environments was significant at $1 \%$ significance, indicating that there is genetic variability among genotypes considering grain yield $\left(\mathrm{kg} \mathrm{ha}^{-1}\right)$. The estimate of the ratio of the highest QMR by the lowest QMR of the individual analysis of variance was 5.2 , indicating that it is possible to analyze the data through the joint analysis, from an average residue.

The variances associated with the random effects of environments and the interaction between genotypes and environments in the joint analysis of variance, were significant $(p<0.01)$, while the effect of genotype was non-significant $(p>$ 0.05 ) (Table 1). The significance of the interaction genotype and environment shows that there is a variation in response of genotypes in different environments, 
indicating the existence of genotypes adapted to particular environments and/or with wider adaptation. Thus, a detailed study of the response of genotypes to environmental variations is necessary, for example, through the analysis of adaptability and stability.

The genotypes UFV91-651226, UFV99-8552093, UFV99-8972162, DM-339, UFV-18 (Patos de Minas), UFV01-871375B, UFV-18-170, M-Soy 8914, UFV0166322813 and UFV99-8552099 showed above average yields above the general average of the experiments, which was $2249.55 \mathrm{~kg} \mathrm{ha}^{-1}$. Of these, DM-338 is specifically adapted to favorable environments $\left(\beta_{1}>1\right)$ and UFV99-8972162 to unfavorable environments $\left(\beta_{1}<1\right)$. The remaining genotypes were indicated as having general adaptability $\left(\beta_{1}=1\right)$ (Table 2 ).

Regarding stability, the genotypes UFV91-651226, UFV99-8552093, UFV01871375B, M-Soy 8914, UFV99-853459, UFV99-9422035 and UFV-2003-334 were classified as high stability, in other words, $\sigma^{2}{ }_{\text {di }}$ statistically equal to zero by the t-test at $5 \%$ significance level. For some genotypes classified as low stability, high $\mathrm{Ri}^{2}$ value (>90\%) was observed.

Table 1. Summary of the joint analysis of variance for grain yield, in $\mathrm{kg} \mathrm{ha}^{-1}$, evaluated in 17 late-cycle soybean genotypes.

\begin{tabular}{lcc}
\hline Variation Sources & Degrees of Freedom & Average Squares $^{1}$ \\
\hline Blocks / Environments & 10 & 112915.6189 \\
Genotypes (G) & 16 & $407998.4758^{\text {ns }}$ \\
Environments (A) & 4 & $52041195.7169^{* *}$ \\
G x A & 64 & $287589.1381^{* *}$ \\
Residue & 160 & 83277.5199 \\
\hline Total & 254 & \\
\hline Average & 2249.55 & \\
Coefficient of variation (\%) & 12.83 & \\
\hline 1** ens: Significant at 1\% significance and not significant, respectively, by Test F.
\end{tabular}

According to Cruz et al. (2004) sometimes it may occur that many cultivars, with higher average yield, present $\sigma 2$ di statistically different from zero. In such cases, these authors suggest that it may be necessary to select cultivars from the group in which stability was low, using the coefficient of determination $\left(\mathrm{Ri}^{2}\right)$ as an auxiliary measure. Thus, the strains UFV99-8972162, UFV01-66322813 and UFV99-8552099 were selected as also having high stability. In this context, Botrel et al. (2005) classified the cultivars Crioula, P-30 and SW 8112A as high stability, considering $\mathrm{Ri}^{2}$ above $80 \%$, when analyzing the method of Eberhart and Russell (1966).

Through the results of ANN, the genotypes BRS-Celeste, DM-339 and UFV999422035 were indicated as having adaptability to favorable environments; UFV998972162 and UFV-2003-334 were indicated for unfavorable environments; and the others as having general adaptability. Regarding stability, the genotypes DM-339 and BRS-Celeste showed low stability (Table 3).

The genotypes that stood out for presenting grain yields above the general average of the environments (experiments) and high phenotypic stability, by the RNA and Eberhart and Russell (1966) methods were UFV91-651226, UFV998552093, UFV01-871375B and M-Soy 8914. These were recommended as having general adaptability (for these two methods), indicating that they do not respond to variation in the environment. 
Table 2. Average grain yield and classification, regarding adaptability and phenotypic stability, of 17 late-cycle soybean genotypes, evaluated in five environments in Minas Gerais, by the Method of Eberhart and Russell (1966).

\begin{tabular}{lcccc}
\hline \multicolumn{1}{c}{ Genotypes } & $\begin{array}{c}\text { Averages } \\
\left(\mathrm{kg} \mathrm{ha}^{-1}\right)\end{array}$ & $\begin{array}{c}\text { Adaptability } \\
\left(\beta_{1}\right)\end{array}$ & $\begin{array}{c}\text { Estability } \\
\left(\sigma_{d i}^{2}\right)\end{array}$ & $R_{\%}^{2}$ \\
\hline UFV-18 (Patos de Minas) & 2366.58 & General & Low & 94.2 \\
BRS-Celeste & 2056.66 & General & Low & 88.5 \\
DM-339 & 2390.00 & Favorable & Low & 87.8 \\
M-Soy 8914 & 2288.33 & General & High & 98.8 \\
UFV01-66322813 & 2277.33 & General & Low & 92.0 \\
UFV99-9422035 & 2062.50 & Favorable & High & 97.4 \\
UFV99-8552093 & 2434.16 & General & High & 97.8 \\
UFV91-651226 & 2603.00 & General & High & 98.8 \\
UFV99-8552099 & 2274.50 & General & Low & 94.5 \\
UFV99-8972162 & 2390.33 & Unfavorable & Low & 90.3 \\
UFV99-853459 & 2176.50 & General & High & 99.9 \\
UFV-18-170 & 2302.66 & General & Low & 88.8 \\
UFV-2003-334 & 2010.83 & Unfavorable & High & 97.2 \\
FT CRISRC7RC135A & 2091.16 & General & Low & 83.0 \\
FT CRISRC7C1PUB1369 & 2108.33 & General & Low & 92.8 \\
UFV01-8553215 & 2075.00 & General & Low & 93.8 \\
UFV01-871375B & 2334.50 & General & High & 96.9 \\
\hline Overall Average & 2249.55 & & & \\
\hline Coefficient of variation (\%) & 12.83 & & & \\
\hline
\end{tabular}

The agreement, regarding the classification of genotypes, between RNA proposed by Nascimento et al. (2013) with the method of Eberhart and Russell (1966) was $94 \%$ in adaptability and in relation to phenotypic stability was $53 \%$. Results obtained by Teodoro et al. (2015) indicated magnitudes of agreement between the methods were $100 \%$ and $70 \%$, respectively for adaptability and phenotypic stability. For high rates of agreement between methods regarding adaptability, Nascimento et al. (2013) suggested that neural networks proved to be an alternative for genotype classification. Regarding stability, Nascimento et al. (2013) reported that the lower percentage of agreement can be explained by the concept of used in the network, since the concept of stability in ANN is based on the work of Finlay and Wilkinson (1963) that differs from Eberhart and Russell (1966) by considering stability as invariance and not predictability.

According to the environmental index proposed by Finlay and Wilkinson (1963) and used in the Centroid Method (Rocha et al., 2005) the environments Capinópolis 1, Capinópolis 2 and Florestal were classified as favorable and Capinópolis 3 and Capinópolis 4 as unfavorable (Table 4).

The Centroid method consists in employing the principal components methodology to represent the information of the differential performance of the genotypes in face of environmental changes and not with the objective of representing the divergence between treatments as this technique is normally employed in breeding and in genetic diversity studies (Rocha et al., 2005). 
Table 3. Average grain yield and classification, regarding adaptability and phenotypic stability, of 17 late-cycle soybean genotypes, evaluated in five environments in Minas Gerais, by the Artificial Neural Network Method proposed by Nascimento et al. (2013).

\begin{tabular}{|c|c|c|c|}
\hline Genotypes & $\begin{array}{l}\text { Averages } \\
\left(\mathrm{kg} \mathrm{ha}^{-1}\right)\end{array}$ & Adaptability & Estability \\
\hline UFV-18 (Patos de Minas) & 2366.58 & General & High $^{1}$ \\
\hline BRS-Celeste & 2056.66 & Favorable $^{1}$ & Low \\
\hline DM-339 & 2390.00 & Favorable & Low \\
\hline M-Soy 8914 & 2288.33 & General & High \\
\hline UFV01-66322813 & 2277.33 & General & High $^{1}$ \\
\hline UFV99-9422035 & 2062.50 & Favorable & High \\
\hline UFV99-8552093 & 2434.16 & General & High \\
\hline UFV91-651226 & 2603.00 & General & High \\
\hline UFV99-8552099 & 2274.50 & General & High $^{1}$ \\
\hline UFV99-8972162 & 2390.33 & Unfavorable & High $^{1}$ \\
\hline UFV99-853459 & 2176.50 & General & High \\
\hline UFV-18-170 & 2302.66 & General & High $^{1}$ \\
\hline UFV-2003-334 & 2010.83 & Unfavorable & High \\
\hline FT CRISRC7RC135A & 2091.16 & General & High $^{1}$ \\
\hline FT CRISRC7C1PUB1369 & 2108.33 & General & High $^{1}$ \\
\hline UFV01-8553215 & 2075.00 & General & High $^{1}$ \\
\hline UFV01-871375B & 2334.50 & General & High \\
\hline Overall average & 2249.55 & & \\
\hline Coefficient of variation (\%) & 12.83 & & \\
\hline
\end{tabular}

Table 4. Classification of environments using the environmental index in the Centroid Method.

\begin{tabular}{lccc}
\hline \multicolumn{1}{c}{ Environments } & $I_{i}$ & Average Yield $\left(\mathrm{kg} \mathrm{ha}^{-1}\right)$ & $\begin{array}{c}\text { Coefficient of } \\
\text { variation (\%) }\end{array}$ \\
\hline (1) Capinópolis 1 & 1429.4 & 3678.9 & 7.1 \\
(2) Capinópolis 2 & 332.4 & 2581.9 & 15.6 \\
(3) Florestal & 182.7 & 2432.2 & 10.2 \\
(4) Capinópolis 3 & -1019.3 & 1230.2 & 14.3 \\
(5) Capinópolis 4 & -925.0 & 1324.5 & 23.1 \\
\hline
\end{tabular}

Obtaining the eigenvalues, via the principal components methodology, starting from the original data including the ideotypes, shows that in this study, only two principal components are sufficient to explain proportions greater than $81 \%$ of the total variation (Table 5). According to Rocha et al. (2005), once the sufficiency of two eigenvalues in representing the total variation is verified, it is possible to evaluate the position of the genotypes in a two-dimensional graph. In this context, the use of graphical analysis, in the Centroid method, with the two principal components are sufficient to explain proportions close to or greater than $80 \%$ of the total variation contained in the original data (Rocha et al., 2005). Barros, 
Sediyama, Teixeira and Cruz (2008), Barros, Sediyama, Teixeira, Reis and Cruz (2009), Nascimento et al. (2009), Barros, Sediyama, Cruz, Teixeira and Reis (2010a) and Barros et al. (2010b) performed the Centroid method analysis and used the graphical analysis, via principal components, with the first two eigenvalues representing $74 \%, 65 \%, 76 \%, 68 \%$ and $65 \%$ of the total variation, respectively.

Table 5. Estimated eigenvalues obtained by the principal components technique and cumulative fraction of the variance explained by these.

\begin{tabular}{ccc}
\hline Root & Root (\%) & Accumulated (\%) \\
\hline 2.165 & 43.296 & 43.30 \\
1.890 & 37.802 & 81.10 \\
0.481 & 9.615 & 90.71 \\
0.306 & 6.122 & 96.83 \\
0.158 & 3.165 & 100.00 \\
\hline
\end{tabular}

The genotypes DM-339 and UFV91-651226 were allocated closer to one of the four ideotypes. However, in general, they were distributed in the central region of the graph (Figure 1). According to Rocha et al. (2005) these points present less similarity with the ideotypes of desired behavior, and therefore their classification in the graph is less precise.

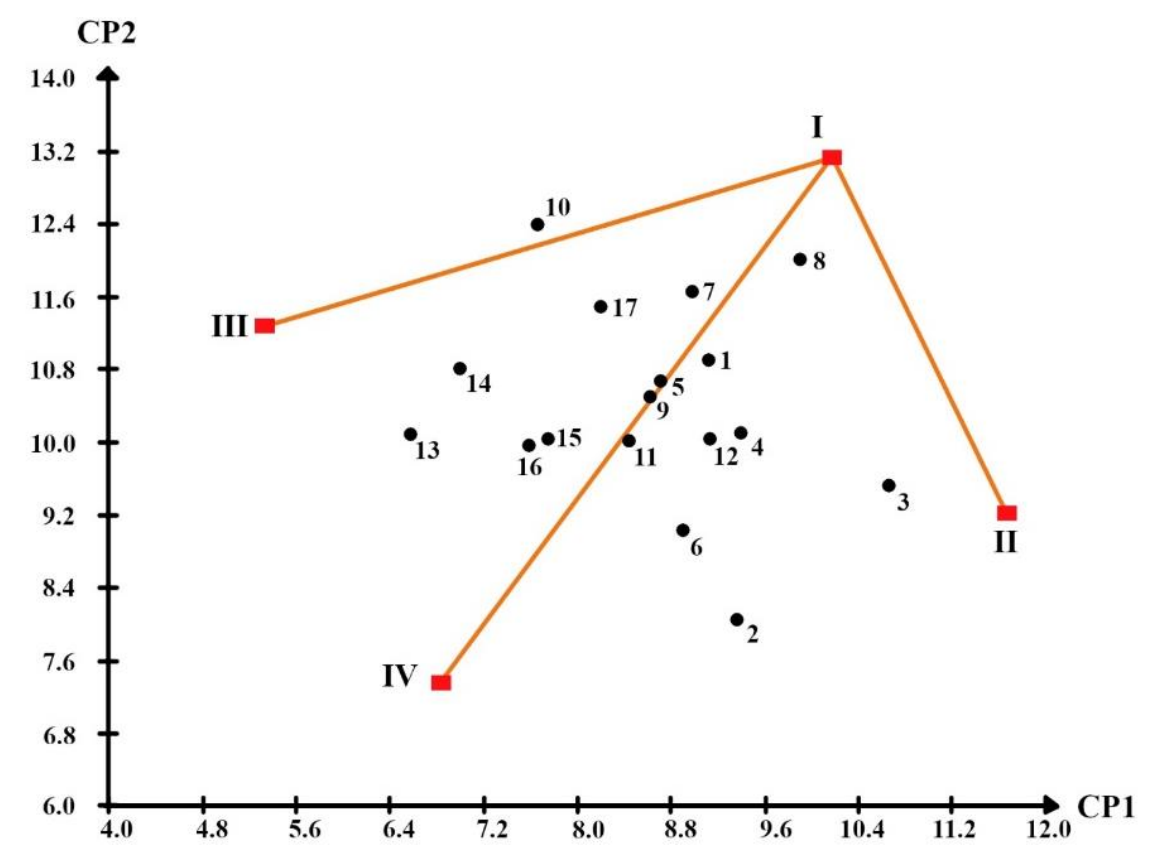

Figure 1. Graphical dispersion of the scores in relation to the first two principal components obtained from the yield analysis of 17 soybean genotypes evaluated in five environments. The four points numbered with Roman numerals represent the centroids. Centroids: I = general adaptability; $I$ = specific adaptability to favorable environments; III = specific adaptability to unfavorable environments; and IV = poorly adapted. Genotypes: 1: UFV-18 (Patos de Minas); 2: BRS-Celeste; 3: DM339; 4: M-Soy 8914; 5: UFV01-66322813; 6: UFV99-9422035; 7: UFV99-8552093; 8: UFV91-651226; 9: UFV99-8552099; 10: UFV99-8972162; 11: UFV99-853459; 12: UFV-18-170; 13: UFV-2003-334; 14: FT CRISRC7RC135A; 15: FT CRISRC7C1PUB1369; 16: UFV01-8553215; and 17: UFV01-871375B. 
The classification of each of the genotypes, regarding adaptability and phenotypic stability, by the Centroid Method is presented in Table 6. A point equidistant to the four reference points presents probability values of $25 \%$ of belonging to any of the groups and, therefore, the more the probability value differs from $25 \%$, the greater the certainty in concluding the grouping of the genotype (Rocha et al., 2005). In addition, they reported that probability values close to or greater than $50 \%$ indicate good clustering reliability.

By the Centroid method and considering the genotypes, that produced more than the general average of the environments, it could be identified that UFV91651226, UFV99-8552093, UFV-18 (Patos de Minas), UFV01-871375B, UFV0166322813 and UFV99-8552099 were classified as being of general adaptability, that is, adapted for wide environmental conditions. DM-339, UFV-18-170 and M-Soy 8914 as being of specific adaptability to favorable environments. UFV99-8972162 recommended for unfavorable environments (Table 4). Of these genotypes, UFV18-170 and M-Soy 8914 were not coincident with the other methods analyzed.

Table 6. Average grain yield and classification, regarding adaptability and phenotypic stability, of 17 late-cycle soybean genotypes, evaluated in five environments in Minas Gerais, by the Centroid method (Rocha et al., 2005).

\begin{tabular}{|c|c|c|c|c|c|c|}
\hline \multirow[b]{2}{*}{ Genotypes } & \multirow{2}{*}{$\begin{array}{l}\text { Average } \\
\quad \mathrm{s} \\
\left(\mathrm{kg} \mathrm{ha}^{-1}\right)\end{array}$} & \multirow[b]{2}{*}{ Class $^{1}$} & \multicolumn{4}{|c|}{ Probability $^{2}$} \\
\hline & & & 1 & II & III & IV \\
\hline UFV-18 (Patos de Minas) & 2366.58 & 1 & 0.311 & 0.279 & 0.210 & 0.199 \\
\hline BRS-Celeste & 2056.66 & II & 0.214 & 0.327 & 0.193 & 0.264 \\
\hline DM-339 & 2390.00 & II & 0.253 & 0.476 & 0.128 & 0.142 \\
\hline M-Soy 8914 & 2288.33 & II & 0.276 & 0.338 & 0.185 & 0.200 \\
\hline UFV01-66322813 & 2277.33 & I & 0.266 & 0.256 & 0.242 & 0.234 \\
\hline UFV99-9422035 & 2062.50 & IV & 0.208 & 0.274 & 0.218 & 0.298 \\
\hline UFV99-8552093 & 2434.16 & I & 0.348 & 0.259 & 0.208 & 0.183 \\
\hline UFV91-651226 & 2603.00 & 1 & 0.490 & 0.249 & 0.136 & 0.123 \\
\hline UFV99-8552099 & 2274.50 & I & 0.280 & 0.265 & 0.231 & 0.222 \\
\hline UFV99-8972162 & 2390.33 & III & 0,281 & 0.195 & 0.317 & 0.206 \\
\hline UFV99-853459 & 2176.50 & IV & 0.236 & 0.246 & 0.252 & 0.264 \\
\hline UFV-18-170 & 2302.66 & II & 0.293 & 0.299 & 0.202 & 0.204 \\
\hline UFV-2003-334 & 2010.83 & III & 0.154 & 0.143 & 0.417 & 0.285 \\
\hline FT CRISRC7RC135A & 2091.16 & III & 0.172 & 0.158 & 0.390 & 0.278 \\
\hline FT CRISRC7C1PUB1369 & 2108.33 & III & 0.210 & 0.206 & 0.296 & 0.286 \\
\hline UFV01-8553215 & 2075.00 & III & 0.194 & 0.191 & 0.313 & 0.301 \\
\hline UFV01-871375B & 2334.50 & 1 & 0.289 & 0.225 & 0.269 & 0.215 \\
\hline Overall Average & 2249.55 & & & & & \\
\hline Coefficient of variation (\%) & 12.83 & & & & & \\
\hline \multicolumn{7}{|c|}{$\begin{array}{l}{ }^{1} \text { Class I: general adaptability; Class II: specific adaptability to favorable environments; } \\
\text { Class III: specific adaptability to unfavorable environments; Class IV: poorly adapted. } \\
\text { 2Probability of belonging to the indicated class. }\end{array}$} \\
\hline
\end{tabular}

In general, the genotypes that presented an average below the general average of the environments were classified as having specific adaptability to unfavorable environments or poorly adapted. Similarly to this work, Barros et al. (2010a) observed a tendency for the average grain yield of soybean genotypes to increase as they approached the centroid I (general adaptability). This is because, according to Rocha et al. (2005), the smaller the difference between any genotype 
and the ideotype I, the smaller the difference between it and the genotype of maximum performance in all environments, making the general adaptability necessarily associated with better performance.

Of the 17 genotypes analyzed, 2 of them (UFV99-853459 and UFV99-9422035) were classified as poorly adapted, and according to Vasconcelos et al. (2008), they may be discarded. These authors suggested that among the 92 varieties analyzed, 25 varieties should be discarded, due to the higher probability of belonging to the class of poorly adapted genotypes.

\section{CONCLUSIONS}

DM-339 is indicated for favorable environments and UFV-18 (Patos de Minas), UFV91-651226, UFV99-8552093, UFV01-871375B, UFV01-66322813 and UFV998552099 are indicated as of general adaptability, considering the three methods of adaptability and stability analysis.

\section{ACKNOWLEDGMENTS}

The authors would like to thank the Coordenação de Aperfeiçoamento de Pessoal de Nível Superior (CAPES) and the Conselho Nacional de Desenvolvimento Científico e Tecnológico (CNPq) for the financial support for this work.

\section{REFERENCES}

Alves, G. F., Nogueira, J. P. G., Machado Junior, R., Ferreira, S. C., Nascimento, M., \& Matsuo, E. (2019). Stability of the hypocotyl length of soybean cultivars using neural networks and traditional methods. Ciência Rural, 49(3), https://doi.org/10.1590/0103-8478cr20180300

Barros, H. B., Sediyama, T., Cruz, C. D., Teixeira, R. C., \& Reis, M. S. (2010b) Análise de adaptabilidade e estabilidade em soja (Glycine max L.) em Mato Grosso. Ambiência, 6(1), $75-88$.

Barros, H. B., Sediyama, T., Teixeira, R. C., \& Cruz, C. D. (2008) Análises paramétricas e não-paramétricas para determinação da adaptabilidade e estabilidade de genótipos de soja. Scientia Agraria, 9, 299-309.

Barros, H. B., Sediyama, T., Teixeira, R. C., Fidelis, R. R., Cruz, C. D., \& Reis, M. S. (2010a) Adaptabilidade e estabilidade de genótipos de soja avaliados no estado do Mato Grosso. Revista Ceres, 57(3), 359-366.

Barros, H. B., Sediyama, T., Teixeira, R. C., Reis, M. S., \& Cruz, C. D. (2009) Adaptabilidade e estabilidade de genótipos de soja, no estado do Mato Grosso. Bioscience Journal, 25(3), 119-128.

Barroso, L. M. A., Nascimento, M., Nascimento, A. C. C., Silva, F., F., \& Ferreira, R.P. (2013) Uso do método de Eberhart e Russell como informação a priori para aplicação de redes neurais artificiais e análise discriminante visando a classificação de genótipos de alfafa quanto à adaptabilidade e estabilidade fenotípica. Revista Brasileira de Biometria, 31(2), 176-188. 
Botrel, M. A., Evangelista, A. R., Viana, M. C. M., Pereira, A. V., Sobrinho, F. S., Oliveira, J. S., Xavier, D. F., \& Heinemann, A. B. (2005) Adaptabilidade e estabilidade de cultivares de alfafa avaliadas em Minas Gerais. Ciência $e$ Agrotecnologia, 29(2), 409-414.

Cruz, C. D. (2013) GENES - a software package for analysis in experimental statistics and quantitative genetics. Acta Scientiarum Agronomy, 35(3), 271-276.

Cruz, C. D., Regazzi, A. J., \& Carneiro, P. C. S. (2004) Modelos biométricos aplicados ao melhoramento genético. ( $3^{\mathrm{a}} \mathrm{ed}$.). Viçosa, MG: Editora UFV.

Cruz, C. D., Rodrigues, H. S., Rosado, R. D. S., \& Bhering, L. L. (2017) Biometria aplicada ao melhoramento genético. In: Silva, F., Borém, A., Sediyama, T., \& Ludke, W. (Eds.) Melhoramento da Soja. Viçosa, MG: Editora UFV, p. 249-287.

Di Mauro, A. O., Curcioli, V. B., Nóbrega, J. C. M., Banzato, D. A., \& Sediyama, T. (2000) Correlação entre medidas paramétricas e não paramétricas de estabilidade de soja. Pesquisa Agropecuária Brasileira, 35(4), 687-696.

Eberhart, S. A., \& Russell, W. A. (1966) Stability parameters for comparing varieties. Crop Science, 6, 36-40.

Finlay, K. W., \& Wilkinson, G. N. (1963) The analysis of adaptation in a plant breeding programme. Australian Journal of Agricultural Research, 14, 742-754.

Nascimento, M., Cruz, C. D., Campana, A. C. M., Tomaz, R. S., Salgado, C. C., \& Ferreira, R. P. (2009) Alteração no método centroide de avaliação da adaptabilidade genotípica. Pesquisa Agropecuária Brasileira, 44(3), 263-269.

Nascimento, M., Nascimento, A. C. C., \& Barroso, L. M. A. (2018) RNA - Aplicação em estudos de adaptabilidade e estabilidade fenotípica. In: Cruz, C. D., \& Nascimento, M. (Eds.). Inteligência Computacional Aplicada ao Melhoramento Genético. Viçosa, MG: Editora UFV, p.278-291.

Nascimento, M., Peternelli, L. A., Cruz, C. D., Nascimento, A. C. C., Ferreira, R. P., Bhering, L. L., \& Salgado, C. C. (2013) Artificial neural networks for adaptability and stability evaluation in alfalfa genotypes. Crop Breeding and Applied Biotechnology, 13(2), 152-156.

Oda, M. C., Sediyama, T., Matsuo, E., Nascimento, M., \& Cruz, C. D. (2019) Estabilidade e adaptabilidade de produção de grãos de soja por meio de metodologias tradicionais e redes neurais artificiais. Revista Scientia Agraria Paranaensis, 18(2), 117-124.

Pimentel-Gomes, F. (1990) Curso de estatística experimental. (13 ${ }^{\mathrm{a}}$ ed.). Piracicaba, Nobel.

R Core Team (2021) R: A language and environment for statistical computing. Vienna, Austria: $\mathrm{R}$ Foundation for Statistical Computing. $\mathrm{R}$ Foundation for Statistical Computing. Retrieved from: www.R-project.org/ 
Rezende, W. S., Cruz, C. D., Borém, A., \& Rosado, R. D. S. (2021) Half a century of studing adaptability and stability in maize and soybean in Brazil. Scientia Agricola, 78(3) http://dx.doi.org/10.1590/1678-992X-2019-0197

Rocha, R. B., Muro-Abad, J. I., Araujo, E. F., \& Cruz, C. D. (2005) Avaliação do método centroide para estudo de adaptabilidade ao ambiente de clones de Eucalyptus grandis. Ciência Florestal, 15, 255-266.

Rodrigues, H. S., Dantas, S. A. G., Ferreira, R. A. D. C., Silva, A. S. L., Cruz, C. D., Schuster, I., \& Silva, F.L. (2020). Adaptabilidade e estabilidade de comportamento. In: Matsuo, E., Cruz, C. D., \& Sediyama, T. (Eds.). Aplicações de técnicas biométricas no melhoramento genético da soja. Londrina, PR: Editora Mecenas, p.165-182.

Santos, M. G. P., Silva, A. F., Sediyama, T., \& Soares, M. M. (2016) Evolução da produção e da produtividade da soja. In: Sediyama T. (Ed). Produtividade da soja. Londrina, PR: Editora Mecenas, p. 19-29.

Sediyama, C. S., Oliveira, L. O., \& Cruz, C. D. (1990) Análise de estabilidade fenotípica de cultivares de soja por meio da regressão linear simples e da regressão linear segmentada. Revista Ceres, 37, 513-518. http://www.ceres.ufv.br/ojs/index.php/ceres/article/download/2001/44

Sediyama, T., Matsuo, É., Oliveira, R. C. T., \& Glasenapp, J. S. (2015) Desenvolvimento de cultivares. In: Sediyama T. (Ed.). Melhoramento Genético da Soja. Londrina, PR: Editora Mecenas. p.82-93.

Teodoro, P. E., Barroso, L. M. A., Nascimento, M., Torres, F. E., Sagrilo, E., Santos, A., \& Ribeiro, L. P. (2015) Redes neurais artificiais para identificar genótipos de feijão-caupi semiprostrado com alta adaptabilidade e estabilidade fenotípica. Pesquisa Agropecuária Brasileira, 50(11), 1054-1060

Vasconcelos, E. S., Barioni-Júnior, W., Cruz, C. D., Ferreira, R. P., Rassini, J. B., \& Vilela, D. (2008) Seleção de genótipos de alfafa pela adaptabilidade e estabilidade da produção de matéria seca. Acta Scientiarum Agronomy, 30(3), 339-343.

Venables, W. N., \& Ripley, B. D. (2002) Modern Applied Statistics with S. (4 ${ }^{\text {th }}$ ed.). New York: Springer-Verlag New York. 